\title{
DEGRADASI ZAT WARNA RHODAMIN B SECARA SONOLISIS \\ MENGGUNAKAN KATALIS $\mathrm{ZnO}-\mathrm{H}_{2} \mathrm{O}_{2}$
}

\author{
Fitrah Amelia \\ Dosen Tetap Prodi pendidikan Matematika Universitas Riau Kepulauan Batam
}

\begin{abstract}
ABSTRAK
Rhodamin B merupakan zat warna sintetis yang bersifat toksik. Untuk mengurangi tingkat toksisitasnya maka dilakukan degradasi terhadap Rhodamin B secara sonolisis menggunakan katalis $\mathrm{ZnO}-\mathrm{H}_{2} \mathrm{O}_{2}$. Metoda sonolisis menggunakan gelombang ultrasonik yang beroperasi pada frekuensi $47 \mathrm{kHz}$. Hasil sonolisis disentrifus untuk memisahkan zat warna dengan katalisnya. Selanjutnya diukur dengan spektrofotometer UV-Vis pada $\lambda 400-600 \mathrm{~nm}$. Dari penelitian yang telah dilakukan diperoleh hasil degradasi dari Rhodamin-B $2 \mathrm{mg} / \mathrm{L}$ dengan penambahan $\mathrm{ZnO}$ efektif $0,3 \mathrm{~g}$ sebesar 35,44\% yang didegradasi selama 60 menit, suhu $40 \pm 1{ }^{\circ} \mathrm{C}, \mathrm{pH} 5$. Pada kondisi yang sama untuk penambahan $3 \mathrm{ml} \mathrm{H}_{2} \mathrm{O}_{2} 30 \%$ didapatkan persen degradasi 42,67 \% dan dengan penambahan $\mathrm{ZnO}-\mathrm{H}_{2} \mathrm{O}_{2}$ diperoleh degradasi sebesar 88,83\%. Persentase degradasi dari Rhodamin B mencapai 91,99\% dengan penambahan $\mathrm{ZnO} 0,3 \mathrm{~g}$ dan $\mathrm{H}_{2} \mathrm{O}_{2} 3$ ml pada $\mathrm{pH}$ 5, suhu $40 \pm 1{ }^{\circ} \mathrm{C}$ setelah disonolisis selama 90 menit.
\end{abstract}

Kata Kunci: Degradasi, Rhodamin B, $\mathrm{TiO}_{2}$-anatase, $\mathrm{ZnO}_{-} \mathrm{H}_{2} \mathrm{O}_{2}$, Sonolisis

\section{PENGANTAR}

Penelitian ini dilakukan untuk mendegradasi polutan organik dalam hal ini zat warna Rhodamin B menggunakan metoda sonolisis. Metoda sonolisis menggunakan gelombang ultrasonic yang beroperasi pada frekuensi antara $20-500 \mathrm{kHz}$. Gelombang ultrasonic dalam air limbah memiliki efisiensi yang besar dalam mendegradasi senyawa yang sukar terurai. Sonolisis mampu mengubah polutan tersebut menjadi senyawa yang kurang berbahaya dibandingkan polutan awal. $\mathrm{ZnO}$ merupakan katalis yang efektif digunakan untuk mendegradasi senyawa-senyawa organik toksik seperti pestisida dan zat warna.

Rhodamin B merupakan zat warna sintetis yang berbentuk serbuk. Umumnya digunakan untuk keperluan pabrik tekstil dan kertas yaitu untuk merubah warna, misal dari warna putih menjadi merah. Rhodamin B adalah zat kimia yang berbahaya sama sekali tidak boleh dicampurkan didalam makanan, minuman dan kosmetik. Rhodamin B mudah larut dalam air dan alkohol, sedikit larut dalam $\mathrm{HCl}$ dan $\mathrm{NaOH}$. Titik leleh $165{ }^{\circ} \mathrm{C} .{ }^{1}$ Pengukuran dengan spektrofotometer UV-Vis menunjukkan $\lambda_{\text {maks }}$ dalam air $553 \mathrm{~nm}$ untuk senyawa netral dan 556 nm dalam bentuk kationnya. ${ }^{2}$ 
Seng (Zn) merupakan jenis logam yang cukup tahan terhadap serangan udara dan air pada temperatur ruang, namun pada suhu tinggi logam ini dapat bereaksi dengan oksigen diudara menghasilkan oksida dalam bentuk $\mathrm{ZnO} .{ }^{3}$ Semikonduktor $\mathrm{ZnO}$ merupakan pilihan yang sesuai untuk alternatif pengganti $\mathrm{TiO}_{2}$ karena disamping tahan terhadap korosi, mempunyai energi celah yang tidak begitu besar, serta rendah dalam pembiayaan. Sebab, walau bagainamapun dalam aplikasinya suatu metoda penanganan masalah lingkungan, rendah biaya juga merupakan prioritas utama. $\mathrm{ZnO}$ lebih efisien daripada $\mathrm{TiO}_{2}$ terutama dalam menghasilkan $\mathrm{H}_{2} \mathrm{O}_{2}$ (radikal) yang menjadi pentransformasi senyawa-senyawa kontaminan bahkan $\mathrm{ZnO}$ lebih ramah terhadap lingkungan dari pada $\mathrm{TiO}_{2}$ sehingga $\mathrm{ZnO}$ dapat diaplikasikan sebagai sumber $\mathrm{H}_{2} \mathrm{O}_{2}$ dalam fototransformasi senyawa-senyawa kontaminan. ${ }^{4}$

Penggunaan $\mathrm{H}_{2} \mathrm{O}_{2}$ pada penelitian ini termasuk pada salah satu metoda Advanced oxidation processes (AOP). AOP adalah satu atau kombinasi dari beberapa proses seperti ozone, hydrogen peroxide, Ultraviolet light, titanium oxide, photo catalyst, sonolysis, electron beam, electrical discharges (plasma) serta beberapa proses lainnya untuk menghasilkan hidroksil radikal

Salah satu keuntungan hidrogen peroksida dibandingkan dengan oksidator yang lain adalah sifatnya yang ramah lingkungan. Ia tidak meninggalkan residu, hanya air dan oksigen. Kekuatan oksidatornya pun dapat diatur sesuai dengan kebutuhan. Sebagai contoh dalam industri pulp dan kertas, penggunaan hidrogen peroksida biasanya dikombinasikan dengan $\mathrm{NaOH}$ atau soda api. Semakin basa, maka laju dekomposisi hidrogen peroksida pun semakin tinggi.

Berdasarkan hal tersebut di atas, maka akan dilakukan penelitian degradasi zat warna Rhodamin B dengan penambahan $\mathrm{ZnO}-\mathrm{H}_{2} \mathrm{O}_{2}$ secara sonolisis. Dimana tujuan dari penelitian ini adalah untuk mengatahui seberapa besar kemampuan katalis $\mathrm{ZnO}-\mathrm{H}_{2} \mathrm{O}_{2}$ bisa mendegradasi zat warna Rhodamin.

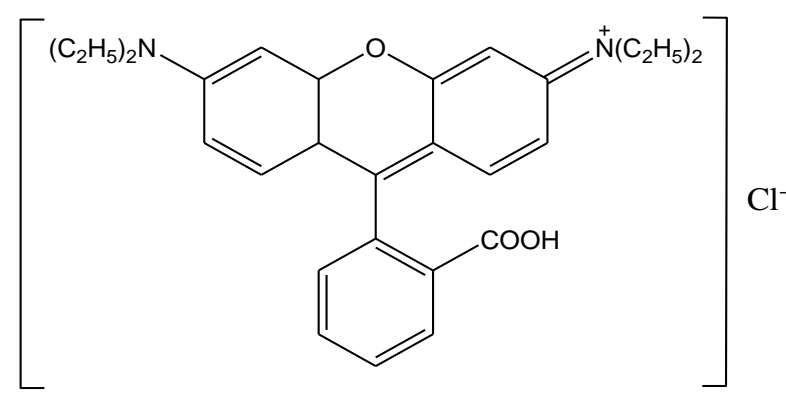

Gambar 1. Struktur Rhodamin $B^{1}$ 


\section{METODOLOGI}

\section{Spektrum Serapan Rhodamin B.}

Sebanyak 1,000 g Rhodamin B dilarutkan dalam $1000 \mathrm{~mL}$ akuades untuk mendapatkan larutan induk Rhodamin B 1000 mg/L. Kemudian larutan induk Rhodamin B 1000 mg/L diencerkan menjadi empat variasi konsentrasi yaitu 1, 2, 3 dan $4 \mathrm{mg} / \mathrm{L}$. Keempat variasi konsentrasi larutan tersebut masing-masing diukur spektrum serapannya dengan spektrofotometer UV-Vis pada $\lambda 400-600 \mathrm{~nm}$.

\section{Penentuan pemakaian efektif $\mathrm{ZnO}$.}

Larutan Rhodamin B 2 mg/L pada pH 5 dimasukkan ke dalam 8 buah botol sebanyak $25 \mathrm{~mL}$. Kemudian ke dalam masing-masing botol ditambahkan $\mathrm{ZnO}$ dengan variasi 0,1; 0,2; 0,$3 ; 0,4 ; 0,5 ; 0,6 ; 0,7 ;$ dan 0,8 g dan ditutup, selanjutnya dilakukan sonolisis pada suhu $40 \pm 1$ ${ }^{\circ} \mathrm{C}$ selama 60 menit. Hasil sonolisis disentrifus untuk memisahkan $\mathrm{ZnO}$ dari larutan. Spektrum serapan masing-masing larutan diukur dengan spektrofotometer UV-Vis pada $\lambda 400-600 \mathrm{~nm}$.

\section{Pemakaian efektif $\mathrm{H}_{2} \mathrm{O}_{2} 30 \%$.}

Larutan Rhodamin B 2 mg/L pada pH 5 dimasukkan ke dalam 7 buah botol sebanyak $25 \mathrm{~mL}$. Kemudian ditambahkan ke dalam masing-masing botol 0,3 g $\mathrm{ZnO}$ dan $\mathrm{H}_{2} \mathrm{O}_{2} 30 \%$ dengan variasi 0,$5 ; 1,0 ; 1,5 ; 2,0 ; 2,5 ; 3,0 ;$ dan $3,5 \mathrm{~mL}$ dan ditutup, selanjutnya dilakukan sonolisis pada suhu $40 \pm 1{ }^{\circ} \mathrm{C}$ selama 60 menit. Hasil sonolisis disentrifus untuk memisahkan $\mathrm{ZnO}$ dari larutan. Spektrum serapan masing-masing larutan diukur dengan spektrofotometer $\mathrm{UV}-\mathrm{V}$ is pada $\lambda 400-600 \mathrm{~nm}$.

\section{Penentuan Persentase Degradasi dengan Variasi Waktu Sonolisis.}

Larutan Rhodamin B 2 mg/L pada pH 5 dimasukkan ke dalam 6 buah botol sebanyak $25 \mathrm{~mL}$. Kemudian ditambahkan ke dalam masing-masing botol 0,3 g $\mathrm{ZnO}$ dan $3 \mathrm{~mL} \mathrm{H}_{2} \mathrm{O}_{2} 30$ $\%$ dan ditutup. Larutan disonolisis pada suhu $40 \pm 1^{\circ} \mathrm{C}$ dengan variasi waktu $0,30,60,90,120$, dan 150 menit. Hasil sonolisis disentrifus untuk memisahkan ZnO dari larutan. Spektrum serapan masing-masing larutan diukur dengan spektrofotometer UV-Vis pada $\lambda 400-600 \mathrm{~nm}$.

\section{HASIL DAN PEMBAHASAN \\ 1. Spektrum Serapan Rhodamin B}

Pengukuran spektrum serapan rhodamin B pada konsentrasi 1, 2, 3, dan 4 mg/L dalam pelarut air menggunakan Spektrofotometer UV-Vis Secomam 1000 memperlihatkan puncak serapan maksimum pada panjang gelombang $551 \mathrm{~nm}$. Dimana panjang gelombang yang didapatkan hampir mendekati yang seharusnya, yaitu $\lambda_{\text {maks }}$ dalam air $553 \mathrm{~nm}$ untuk senyawa netral dan $556 \mathrm{~nm}$ dalam bentuk kationnya. ${ }^{2}$ 


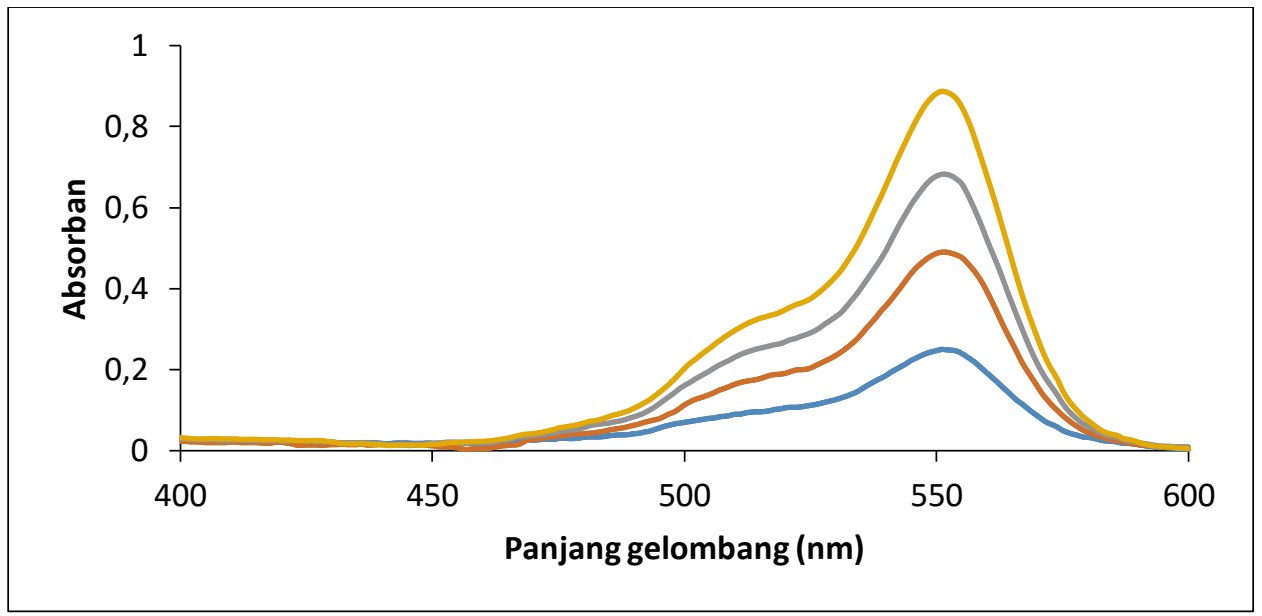

Gambar 2. Spektrum serapan Rhodamin B pada variasi konsentrasi

Ket $:(\longrightarrow$ Rhodamin B $1 \mathrm{mg} / \mathrm{L},(\longrightarrow$ Rhodamin B $2 \mathrm{mg} / \mathrm{L},(\longrightarrow$ Rhodamin B $3 \mathrm{mg} / \mathrm{L},(\longrightarrow)$ Rhodamin B 4 mg/L

\section{Pemakaian efektif $\mathrm{ZnO}$}

Efek dari ultrasonik menghasilkan fenomena yang dikenal sebagai kativasi akustik. Proses kavitasi tersebut terdiri dari pembentukkan, pertumbuhan dan mengembang mengempisnya gelembung pada larutan. Kavitasi tersebut memberikan efek fisik dan kimia tertentu yang berperan dalam proses degradasi senyawa. Efek fisik yang ditimbulkan oleh proses kavitasi adalah meningkatnya reaktifitas katalis melalui perluasan permukaan, sedangkan efek kimia yang terjadi adalah meningkatnya kecepatan reaksi pembentukkan spesies aktif yang berperan dalam degradasi senyawa. Untuk meningkatkan efisiensi degradasi sonolisis ditambahkan katalis yang dapat meningkatkan produksi radikal $\mathrm{OH}$ sehingga mempercepat proses degradasi senyawa organik.

Penambahan $\mathrm{ZnO}$ berfungsi sebagai katalis yang membantu proses degradasi dari Rhodamin B. Dengan adanya katalis maka degradasi dari Rhodamin B akan berlangsung lebih cepat dari pada tanpa menggunakan katalis. Sifat katalis yang dapat mempercepat reaksi dan tidak ikut bereaksi memudahkan kita untuk memisahkan kembali $\mathrm{ZnO}$ dari zat aktifnya. Pemisahan dapat dilakukan dengan menggunakan sentrifus. 


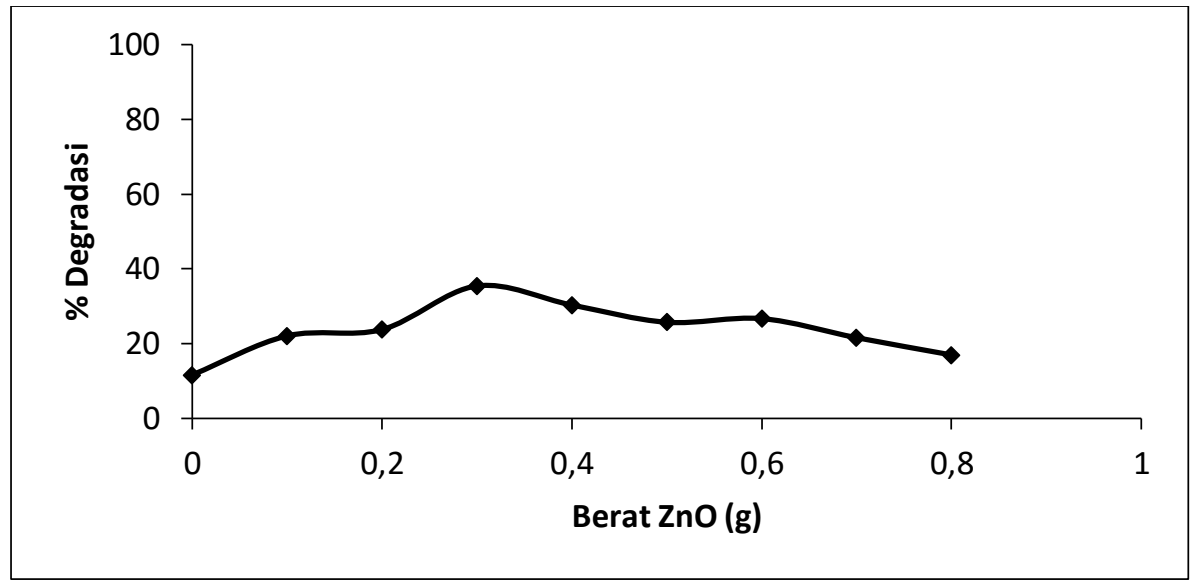

Gambar 3. Kurva pengaruh penambahan $\mathrm{ZnO}$ terhadap persen degradasi Rhodamin $\mathrm{B}$ setelah disonolisis Ket : [Rhodamin B] : $2 \mathrm{mg} / \mathrm{L}, \mathrm{pH}$ 5, Suhu $40 \pm 1^{\circ} \mathrm{C}$, sonolisis selama 60 menit

Gambar 3 menunjukkan bahwa persentase degradasi dari Rhodamin B meningkat saat dilakukannya penambahan $\mathrm{ZnO}$, namun terjadi penurunan persentase degradasi pada saat penambahan $\mathrm{ZnO}$ mulai dari 0,4 gram sampai 0,8 gram. Ini disebabkan karena adanya intermediet dari Rhodamin B yang ikut terukur pada saat pengukuran menggunakan spektrofotometer UV-Vis, serta akibat terjadinya reaksi antara intermediet dengan oksidan yang tersedia sehingga menghalangi zat aktif bereaksi dengan oksidan $\left(\mathrm{OH}^{*}, \mathrm{O}_{2}{ }^{\circ}, \mathrm{HO}_{2}{ }^{\circ}\right) .^{5}$ Senyawa intermediet terbentuk akibat rusaknya senyawa organik. Senyawa intermediet merupakan senyawa antara dari hasil reaksi zat aktif dengan $\mathrm{OH}^{\circ}$ sebelum diperoleh hasil akhir berupa $\mathrm{CO}_{2}$ dan $\mathrm{H}_{2} \mathrm{O} .{ }^{6}$ Dari hasil pengukuran menunjukkan pemakaian $\mathrm{ZnO} 0,3$ gram yang efektif. Dengan penambahan 0,3 gram ZnO sudah terjadi penurunan nilai absorban yang cukup berarti (Lihat gambar 4) dan diperoleh persentase degradasinya 35,44 \%. Untuk perlakuan selanjutnya dipakai $\mathrm{ZnO}$ efektif yaitu 0,3 gram.

Degradasi Rhodamin B menggunakan katalis $\mathrm{TiO}_{2}$ diperoleh persen degradasinya sebesar 40,81 \%. Sedangkan dengan $\mathrm{ZnO}$ hanya 35,44 \% Rhodamin B yang terdegradasi. Dapat dilihat bahwa perbedaan persentase degradasi Rhodamin $\mathrm{B}$ menggunakan $\mathrm{TiO}_{2}$ dengan menggunakan $\mathrm{ZnO}$ tidak begitu signifikan. Ini berarti $\mathrm{ZnO}$ dapat digunakan sebagai katalis alternatif pengganti $\mathrm{TiO}_{2}$. 


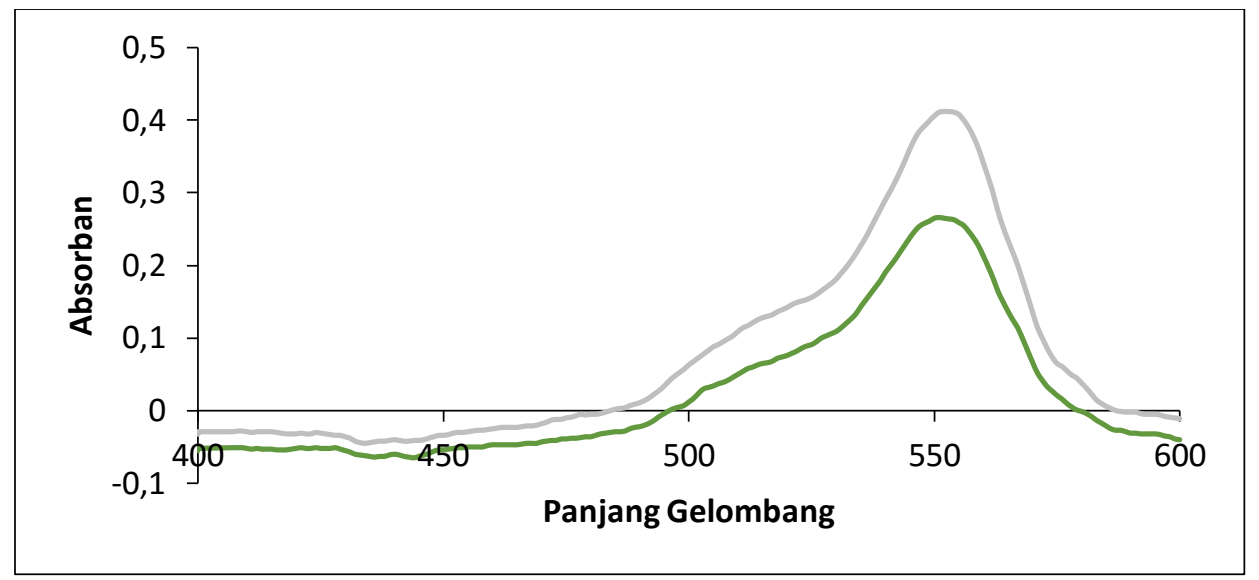

Gambar 4. Spektrum serapan Rhodamin B sebelum dan sesudah disonolisis Variasi penambahan $\mathrm{ZnO}$ Ket : ( ) Rhodamin B sebelum disonolisis, Rhodamin B setelah disonolisis $(-)$

\section{Pemakaian efektif $\mathrm{H}_{2} \mathrm{O}_{2} 30 \%$ dengan dan tanpa penambahan $\mathrm{ZnO}$}

Penambahan $\mathrm{H}_{2} \mathrm{O}_{2}$ membantu dalam mempercepat proses degradasi. Penambahan hidrogen peroksida yang yang berlebihan dapat bertindak sebagai Pengurai $\mathrm{OH}^{*}$. Karena itu penambahan yang tepat dari hidrogen peroksida bisa mempercepat laju degradasi. Agar dapat menjaga efisiensi dari penambahan $\mathrm{H}_{2} \mathrm{O}_{2}$, dibutuhkan untuk memilih takaran yang tepat dari $\mathrm{H}_{2} \mathrm{O}_{2}$ menurut jenis dan konsentrasi dari polutan. Penambahan $\mathrm{H}_{2} \mathrm{O}_{2}$ akan menghasilkan air $\left(\mathrm{H}_{2} \mathrm{O}\right)$ dan oksigen $\left(\mathrm{O}_{2}\right)$ seperti yang dapat dilihat pada reaksi berikut :

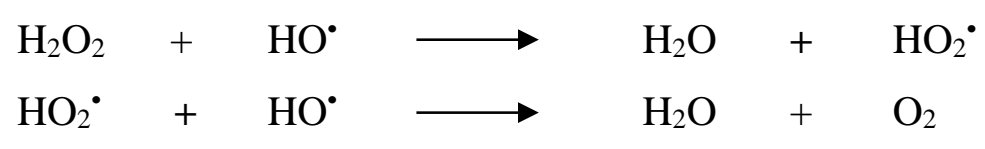

Pada saat konsentrasi hidrogen peroksida rendah akan meningkatkan laju dari formasi radikal hidroksil, pada konsentrasi hidrogen peroksida sangat tinggi akan dihasilkan penurunan laju degradasi. ${ }^{7}$ Persentase degradasi Rhodamin B tanpa sonolisis dapat dilihat pada gambar 5 dimana hasil degradasi yang di dapatkan tidak terlalu besar, sehingga dapat dikatakan bahwa yang mempengaruhi perubahan persen degradasi dari Rhodamin $\mathrm{B}$ hanya radikal $\mathrm{OH}$ dari $\mathrm{H}_{2} \mathrm{O}_{2}$ saja.

Persentase degradasi Rhodamin $\mathrm{B}$ yang ditambahkan $\mathrm{H}_{2} \mathrm{O}_{2}$ dan tanpa katalis $\mathrm{ZnO}$ dihasilkan lebih kecil dibandingkan setelah dikombinasikan dengan $\mathrm{ZnO}$. Ini dapat dilihat pada Gambar 6. Dimana pada saat penambahan $3 \mathrm{ml} \mathrm{H}_{2} \mathrm{O}_{2}$ hanya 42,67 \% Rhodamin B yang terdegradasi. Ini disebabkan karena kombinasi dari katalis dengan $\mathrm{H}_{2} \mathrm{O}_{2}$ berperan penting untuk meningkatkan laju degradasi. Pada konsentrasi tinggi radikal hidroksil dihasilkan dari efek sinergi semikonduktor dengan hidrogen peroksida. ${ }^{6}$ Namun pada saat penambahan $3,5 \mathrm{ml} \mathrm{H}_{2} \mathrm{O}_{2}$ tidak terjadi perubahan yang signifikan terhadap persen degradsi dari Rhodamin B sehingga 
penambahan $3 \mathrm{ml} \mathrm{H} \mathrm{O}_{2}$ merupakan pemakaian $\mathrm{H}_{2} \mathrm{O}_{2}$ yang efektif dan ini digunakan untuk perlakuan selanjutnya.

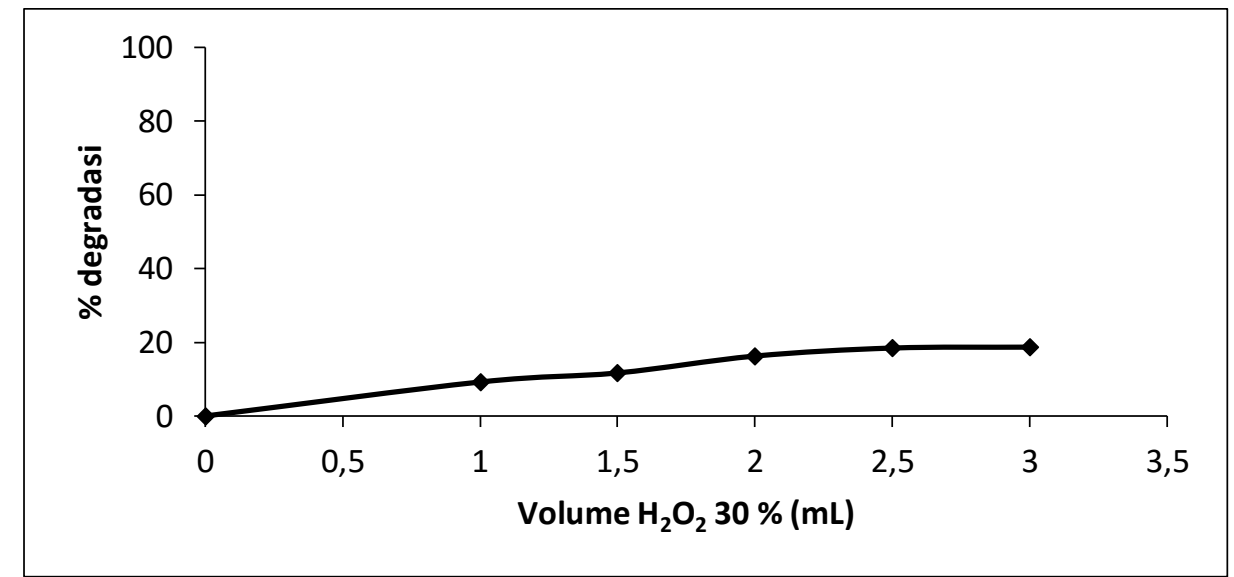

Gambar 5. Kurva pengaruh penambahan $\mathrm{H}_{2} \mathrm{O}_{2}$ terhadap persen degradasi Rhodamin $\mathrm{B}$ tanpa sonolisis Ket : [Rhodamin B] : $2 \mathrm{mg} / \mathrm{L},\left[\mathrm{H}_{2} \mathrm{O}_{2}\right]: 30 \%$, pH 5, Suhu $40 \pm 1{ }^{\circ} \mathrm{C}$, dibiarkan selama 60 menit

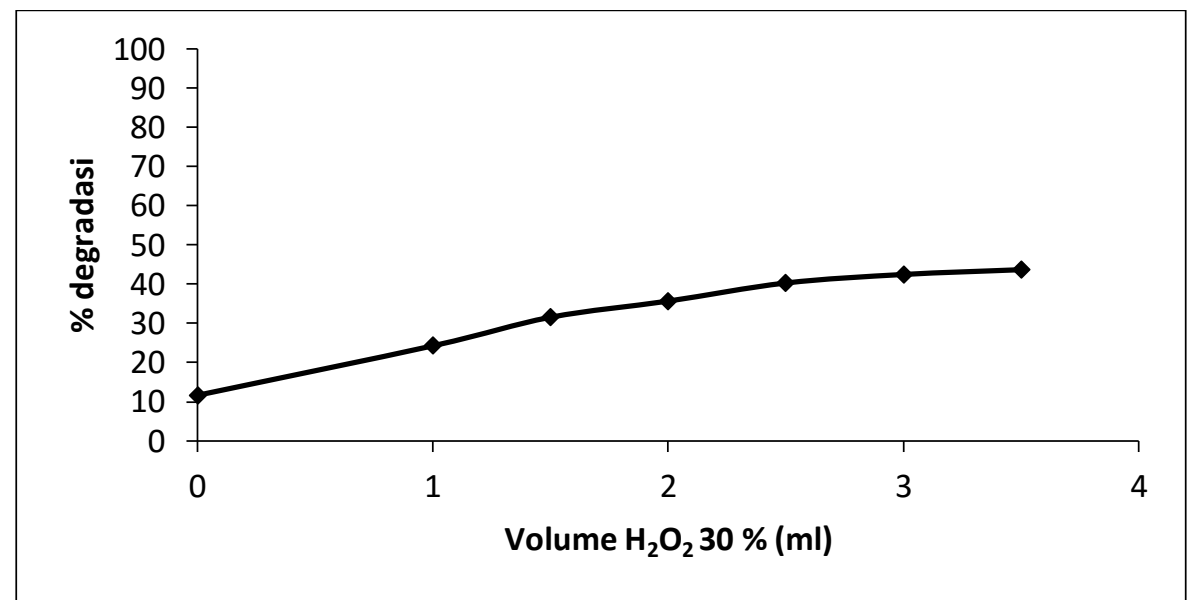

Gambar 6. Kurva pengaruh penambahan $\mathrm{H}_{2} \mathrm{O}_{2}$ terhadap persen degradasi Rhodamin $\mathrm{B}$ setelah disonolisis

Ket : [Rhodamin B] : $2 \mathrm{mg} / \mathrm{L},\left[\mathrm{H}_{2} \mathrm{O}_{2}\right]: 30 \%$, pH 5, Suhu $40 \pm 1{ }^{\circ} \mathrm{C}$, sonolisis selama 60 menit

Untuk meningkatkan persentase degradasi dari Rhodamin B maka dilakukan penambahan $\mathrm{H}_{2} \mathrm{O}_{2}$. Hidrogen peroksida merupakan oksidator kuat yang dapat membantu katalis $\mathrm{ZnO}$ dalam mendegradasi zat warna Rhodamin B. semakin banyak $\mathrm{H}_{2} \mathrm{O}_{2}$ yang digunakan dalam mendegradasi Rhodamin B semakin besar persentase degradasi dari Rhodamin B dan semakin kecil nilai serapan absorbanya. Dalam kondisi normal hidrogen peroksida sangat stabil, dengan laju dekomposisi yang sangat rendah. Ini dapat dilihat pada Gambar 7. 


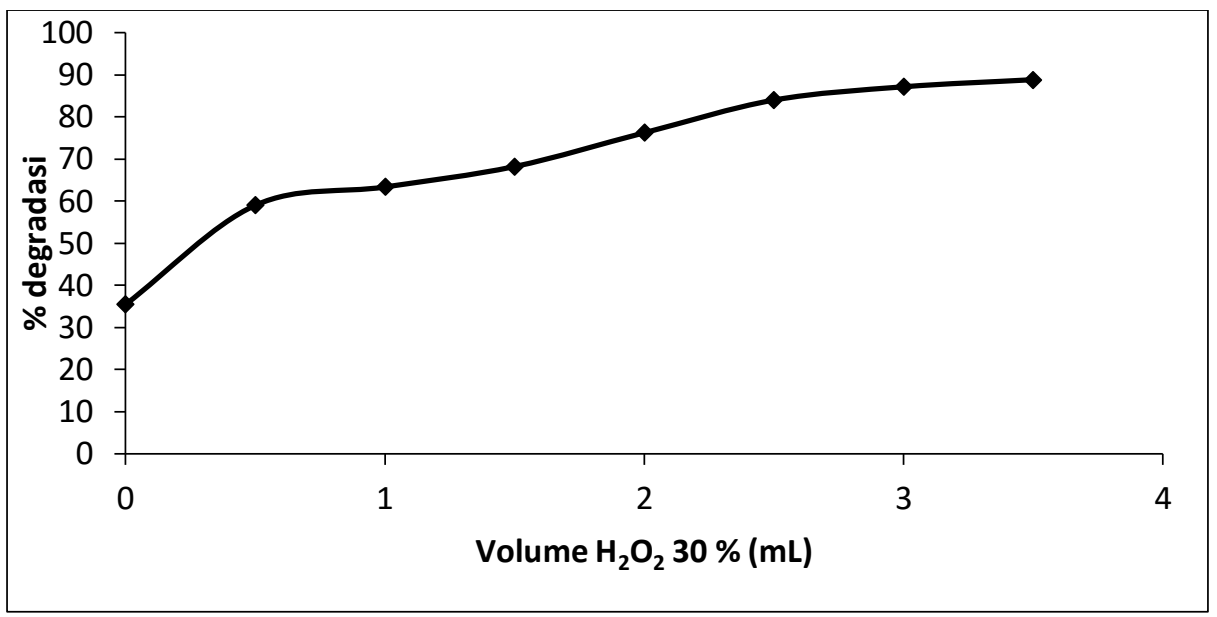

Gambar 7. Kurva pengaruh penambahan, $\mathrm{ZnO}-\mathrm{H}_{2} \mathrm{O}_{2}$ terhadap persen degradasi Rhodamin $\mathrm{B}$ setelah disonolisis

Ket : [Rhodamin B] : $2 \mathrm{mg} / \mathrm{L},\left[\mathrm{H}_{2} \mathrm{O}_{2}\right]$ : $30 \%, \mathrm{pH}$, $\mathrm{ZnO} 0,3 \mathrm{~g}$, Suhu $40 \pm 1{ }^{\circ} \mathrm{C}$, sonolisis selama 60 menit

Saat dilakukan sonolisis larutan dari Rhodamin B yang berisi $\mathrm{H}_{2} \mathrm{O}_{2}$ dan $\mathrm{ZnO}$ tersebut mengalami perubahan warna dari merah muda menjadi putih yang sedikit merah muda. Perubahan ini dapat diamati secara visual yang ditandai dengan timbulnya gelembunggelembung pada botol yang berisi larutan. Ini menyebabkan pemisahan Rhodamin B dari katalisnya cukup sulit untuk dilakukan sehingga dibutuhkan sentrifus yang beruang-ulang kali dan waktu sentrifus yang lama. Perubahan warna tidak terjadi pada saat sonolisis larutan Rhodamin B yang hanya mengandung $\mathrm{ZnO}$ atau $\mathrm{H}_{2} \mathrm{O}_{2}$ saja. Dengan ditambahkannya $\mathrm{H}_{2} \mathrm{O}_{2} \mathrm{ke}$ dalam larutan Rhodamin B yang dikombinasikan dengan $\mathrm{ZnO}$ menyebabkan persentase degradasi dari Rhodamin $\mathrm{B}$ meningkat dua kali lipat dibandingkan tanpa penambahan $\mathrm{H}_{2} \mathrm{O}_{2}$ yaitu dari $35,44 \%$ menjadi $87,14 \%$ sedangkan serapan absorbannya menurun. Terjadinya peningkatan degradasi saat katalis dan $\mathrm{H}_{2} \mathrm{O}_{2}$ di sonolisis secara bersamaan disebabkan karena katalis dapat menghasilkan Radikal $\mathrm{OH}$ tambahan dan mempercepat proses sonolisis. Sehingga didapatkan volume efektif $\mathrm{H}_{2} \mathrm{O}_{2}$ sebesar $3 \mathrm{ml}$ dan volume ini nantinya yang akan digunakan pada penelitian selanjutnya. Diambil $3 \mathrm{ml}$ sebagai volume efektifnya disebabkan oleh persentase degradasi dari Rhodamin B tidak begitu jauh peningkatannya pada saat dilakukan penambahan $\mathrm{H}_{2} \mathrm{O}_{2} 3,5 \mathrm{ml}$.

Gambar 8 memperlihatkan perubahan \% degradasi yang terjadi saat Rhodamin B ditambahkan $\mathrm{H}_{2} \mathrm{O}_{2}$ tanpa disonolisis, dengan sonolisis serta penambahan $\mathrm{ZnO}-\mathrm{H}_{2} \mathrm{O}_{2}$ setelah disonolisis. Dimana Persen degradasi tanpa disonolisis lebih kecil dari yang di sonolisis sedangkan yang disonolisis juga lebih kecil dari pada setelah penambahan $\mathrm{ZnO}-\mathrm{H}_{2} \mathrm{O}_{2}$ setelah disonolisis. 


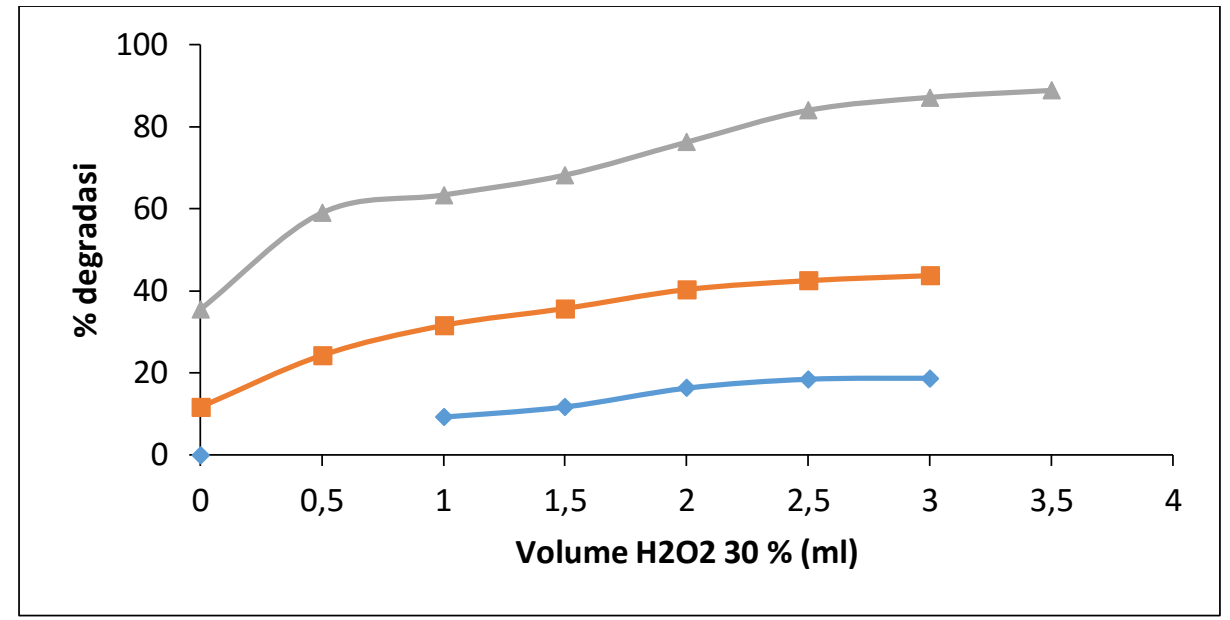

Gambar 8. Kurva pengaruh penambahan $\mathrm{H}_{2} \mathrm{O}_{2}$ terhadap persen degradasi Rhodamin $\mathrm{B}$

Ket : [Rhodamin B] : $2 \mathrm{mg} / \mathrm{L},\left[\mathrm{H}_{2} \mathrm{O}_{2}\right.$ ] : $30 \%$, pH 5, Suhu $40 \pm 1{ }^{\circ} \mathrm{C}$, sonolisis selama 60 menit. ( Rhodamin B tanpa sonolisis, $(\longrightarrow$ setelah di sonolisis, $(\longrightarrow$ setelah penambahan $\mathrm{ZnO}$ dan disonolisis.

\section{Persentase Degradasi dengan Variasi Waktu Sonolisis}

Sonolisis Rhodamin B $2 \mathrm{mg} / \mathrm{L}, \mathrm{pH} 5$, suhu $40 \pm 1^{\circ} \mathrm{C}$ dengan penambahan $\mathrm{ZnO}$ 0,3 gram dan $3 \mathrm{ml} \mathrm{H}_{2} \mathrm{O}_{2}$ dilakukan selama 150 menit dengan interval 30 menit. Gambar 9 menunjukkan bahwa persentase degradasi Rhodamin $\mathrm{B} 2 \mathrm{mg} / \mathrm{L}$, pH 5, suhu $40 \pm 1{ }^{\circ} \mathrm{C}, \mathrm{ZnO} 0,3 \mathrm{~g}, \mathrm{H}_{2} \mathrm{O}_{2} 3 \mathrm{ml}$ mengalami kenaikan sampai pada waktu 90 menit. Struktur Rhodamin B yang rumit menyebabkan tidak mudah untuk didegradasi dalam waktu yang singkat. Penggunaan alat sonolisis dengan kekuatan energi getaran dan daya yang lebih tinggi memungkinkan proses degradasi berlangsung lebih cepat.

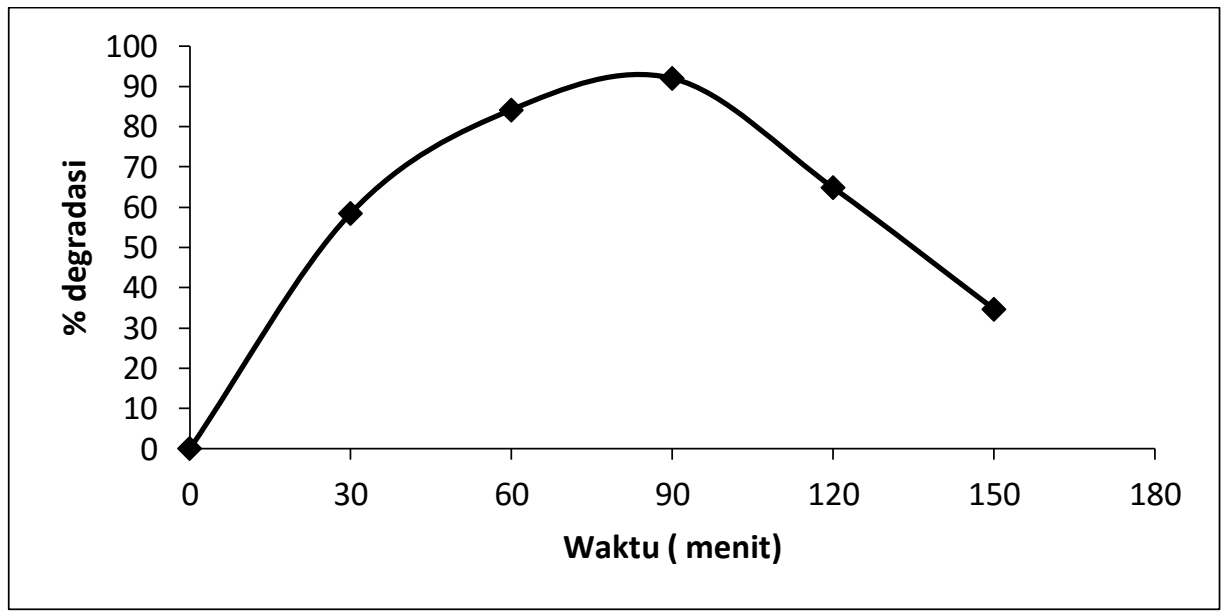

Gambar 9. Kurva persentase degradasi Rhodamin B terhadap variasi waktu sonolisis Ket : [Rhodamin B] : $2 \mathrm{mg} / \mathrm{L}, \mathrm{pH} 5, \mathrm{ZnO} 0,3 \mathrm{~g}, \mathrm{H}_{2} \mathrm{O}_{2} 30 \% 3 \mathrm{ml}$, Suhu $40 \pm 1{ }^{\circ} \mathrm{C}$

Dari hasil dapat dilihat penurunan nilai serapan pada panjang gelombang 552,6 $\mathrm{nm}$. Untuk mendegradasi Rhodamin B 2 mg/L sebesar 91,99 \% dibutuhkan waktu 90 menit. 
Penurunan nilai serapan Rhodamin B setelah penambahan $\mathrm{ZnO}-\mathrm{H}_{2} \mathrm{O}_{2}$ terhadap serapan awal dari Rhodamin B dapat dilihat pada Gambar 10.

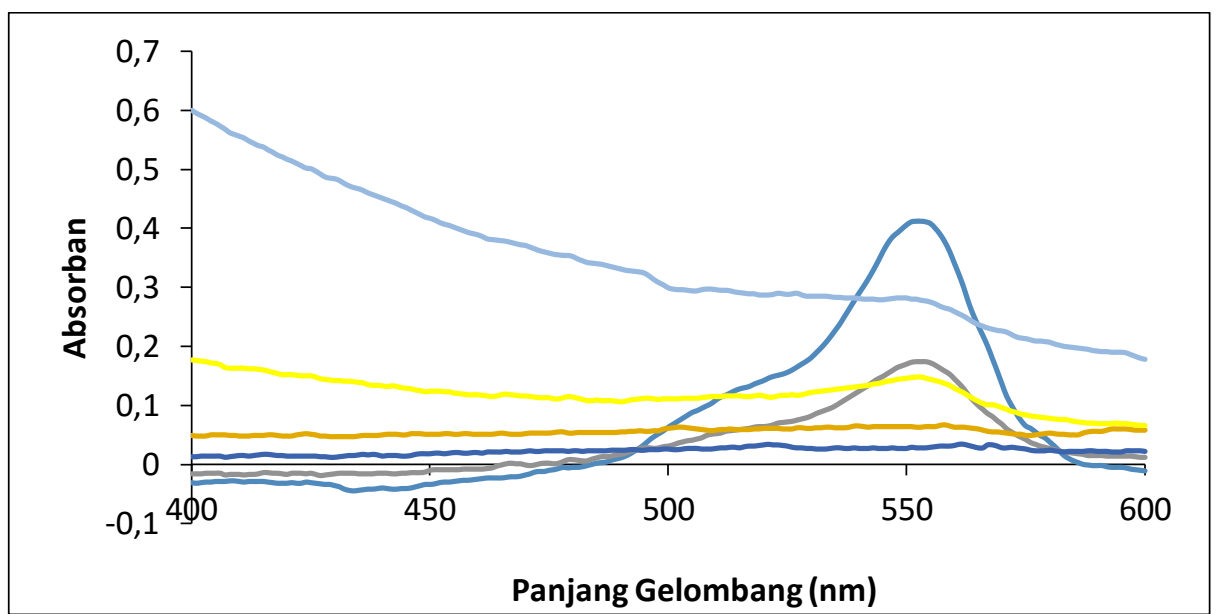

Gambar 10. Spektrum serapan Rhodamin B sebelum dan sesudah disonolisis

Ket : $\Longleftrightarrow$ Rhodamin B sebelum disonolisis, Rhodamin B setelah disonolisis ( $)-30$ menit, $(\Longrightarrow)$ 60 menit, (_) 90 menit, ( ) 120 menit, dan ( ) 150 menit dengan penambahan $\mathrm{ZnO} 0,3 \mathrm{~g}$ dan $\mathrm{H}_{2} \mathrm{O}_{2} 30 \% 3 \mathrm{ml}$.

Persentase degradasi kembali mengalami penurunan setelah didegradasi lebih dari 90 menit. Hal ini disebabkan karena $\mathrm{H}_{2} \mathrm{O}_{2}$ yang ditambahkan tersebut $\mathrm{OH}^{\bullet}$ nya telah habis terdekomposisi atau terurai, atau terjadinya reaksi dengan katalis dan membentuk senyawa perokso yang mana akan mengganggu proses sonolisis. ${ }^{5}$ Selain itu penurunan persen degradasi ini juga disebabkan karena terbentuknya koloid sehingga sulit untuk dipisahkan dengan sentrifus akibatnya pada saat pengukuran menggunakan UV-Vis sampel yang diukur tingkat kekeruhannya masih tinggi. Pada saat waktu 120 dan 150 menit memberikan hasil pengukuran menggunakan UV-Vis berupa garis melayang pada bagian atas kurva. Tidak ada spektrum serapan yang terbaca pada panjang gelombang $553 \mathrm{~nm}$. Warna larutan bila dilihat secara visual sudah menjadi keruh dengan sedikit warna merah.

\section{KESIMPULAN DAN SARAN}

\section{Kesimpulan}

Dari penelitian yang telah dilakukan dapat disimpulkan bahwa $\mathrm{ZnO}-\mathrm{H}_{2} \mathrm{O}_{2}$ dapat meningkatkan persentase degradasi dari Rhodamin-B setelah didegradasi menggunakan sonolisis. Dimana untuk penambahan katalis $\mathrm{ZnO}$ diperoleh persen degradasi sebesar 35,44 \% . Untuk penambahan $\mathrm{H}_{2} \mathrm{O}_{2} 30 \%$ persen degradasi didapatkan sebesar 42,67\% dan $\mathrm{ZnO}-\mathrm{H}_{2} \mathrm{O}_{2}$ didapatkan persen degradasi $87,14 \%$ yang disonolisis selama 60 menit, sedangkan untuk Rhodamin B $2 \mathrm{mg} / \mathrm{L}$ menggunakan katalis $\mathrm{ZnO} 0,3 \mathrm{~g}$ dan $\mathrm{H}_{2} \mathrm{O}_{2} 3 \mathrm{ml}$ pada $\mathrm{pH}$, suhu $40 \pm 1{ }^{\circ} \mathrm{C}$, selama 90 menit mencapai $91,99 \%$. 


\section{Saran}

Bagi peneliti selanjutnya disarankan untuk mengidentifikasi produk sonolisis yang terbentuk pada beberapa tahap perlakuan dengan metoda HPLC serta mengidentifikasi fungsi penambahan $\mathrm{H}_{2} \mathrm{O}_{2}$ pada penelitian ini. Apakah pada penelitian ini $\mathrm{H}_{2} \mathrm{O}_{2}$ berfungsi sebagai katalis, oksidator atau keduannya, sehingga dapat diketahui secara jelas.

\section{DAFTAR PUSTAKA}

1. The merck Index, An Encyclopedia of Chemicals, drugs, and biologicals, Thirteenth edition. Merck \& Co., Inc. (2001), p 1085.

2. H. Park, W. Choi, Photocatalytic Reactivities of Nafion-Coated $\mathrm{TiO}_{2}$ for the Degradation Charged Organic Compounds Under UV or Visible Light, J. Phys, Chem. B, 109 : 1166711674 (2005).

3. Darajat. S, Hermansyah Aziz, dan Admin Alif. Seng Oksida (ZnO) sebagai Fotokatalis pada Proses Degradasi Senyawa Biru Metilen. J. Ris. Kim. 1 (2) 179-186 (2008).

4. M. R. Hoffman, S. T. Martin, W. Choi, D. W. Bahneman, Environmental Aplication of Semiconductors Photocatalysis. Chem Review, 95 : 71-87. (1995).

5. A. Eslami, S. Nasseri, B. Yodollahi, A. Mesdaghinia, F. Vaezi, R. Nabizadeh, Application of photocatalytic process for removal of Methyl Tert-Butyl Ether from highly contaminated water, Iran. J. Environ. Health. Sci. Eng, 4 (4) : 215-222.

6. I. Poulios, D. Makri, X. Prohaska. Photocatalytic Treatment of Olive Milling Waste Water : Oxidation of Protocatechuic Acid. Global Nest: the Int. J. 1 (1) 55-62 (1999).

7. D. D. Dionysiou, M. T. Suidan, E. Bekou, I. Baudin, J. M. laine. Effect of ionic strength and hydrogen peroxide on the Photocatalytic degradation of 4-chlorobenzoic acid in water, Appl. Catalysis B: Environ. 26 : 153-171 (2000). 